\title{
Mulching Effects and Nitrogen Application on the Performance of Zea mays L: Crop Growth and Nutrient Accumulation
}

\author{
Oroka, Frank O. \\ Department of Agronomy, \\ Delta State University, Asaba Campus, \\ Delta State, Nigeria \\ Email:orkfra@yahoo.com
}

Keywords: Mulching, foliage, organic residues, maize, nutrient uptake

\begin{abstract}
Maize is an agronomic cereal species that is sensitive to nutrient applications, especially nitrogen. Field experiments were conducted in 2011 and 2012 to evaluate the effect of nitrogen and mulching using dried weeds on maize growth and nutrient accumulation. The study was located in the Research Farm of the Agricultural Science Education Unit of the Delta State University, Abraka, Nigeria ((latitude $5^{0} 46^{\prime} \mathrm{N}$ and longitude $\left.6^{0} 5^{\prime} \mathrm{E}\right)$. The experiment consist of eight (8) treatments (i) control (ii) $40 \mathrm{kgNha}^{-1}$ (iii) $80 \mathrm{kgNha}^{-1}$ (iv) $120 \mathrm{kgNha}^{-1}$ (v) $4.5 \mathrm{t} \mathrm{ha}^{-1}$ Panicum maximum $+40 \mathrm{kgNha}^{-1}$ (vi) $4.5 \mathrm{t} \mathrm{ha}^{-1}$ Pueraria phaseoloides $+40 \mathrm{kgNha}^{-1}$ (vii) $4.5 \mathrm{t} \mathrm{ha}^{-1}$ Eleusine indica + $40 \mathrm{kgNha}^{-1}$ (viii) $4.5 \mathrm{t} \mathrm{ha}^{-1}$ Stylosanthes gracilis $+40 \mathrm{kgNha}^{-1}$. The treatments were replicated three times. From research results, the combination of Pueraria phaseoloides with $40 \mathrm{kgNha}^{-1}$ showed higher maize plant height, foliage development attributes, shoot dry matter, crop growth indices and nutrient uptake compared to other combinations, while only nitrogen application of $120 \mathrm{kgNha}^{-1}$ recorded the highest in all the treatments. It can be concluded based on the results in this study, that legume based weeds as mulch can be supplemented with nitrogen to improve maize growth.
\end{abstract}

\section{Introduction}

Continuous cultivation in tropical Africa, an aftermath of limited land for agriculture due to population pressure has remained a threat to soil productivity and crop production. Maize (Zea mays L.) a nitrogen demanding crop, is one of such crops under continuous cultivation. It is one of the most important cereal in Nigeria next to rice, because of its role in livestock and human consumption and in industrial food and non-food products (Kehinde, 1999, Ademiluyi, 2014).

Plant residues such as cleared weeds are usually burnt or packed out of farm and allowed to decay, especially in situations where the farmer is neither cultivating vegetables nor yam. However these cleared dried weeds or plant residues being organic in nature are rich source in soil nutrients (Memon, et al, 2012) hence can be recycled into the farmland to provide macro and micronutrients to the cultivated crops as well as providing and sustaining a balanced agroecosystem.

Application of mineral fertilizer on crop land on a continuous basis promotes soil acidification and reduction in soil organic matter (Ehui et al., 1994). As a way of improving productivity of farmlands, sustainable options which will result in efficient recycling of organic material are being considered for adoption by small holder farmers. Integrated systems which combine chemical fertilizers with plant materials such as dried weeds are needed to improve soil organic matter and provide a favourable environment for microbial activity (Akobundu, 1993). Use of plant materials as mulch are known to positively improve soil physical properties, increase availability of soil nutrients and soil flora and fauna populations. When legume weeds are used the demand for nitrogen fertilizer is reduced (Akobundu, 1993). Efficient use of chemical fertilizer and organic plant residues in maize production are measures that has been shown to enhance and increase maize growth and nutrient uptake, which forms the basis for higher crop yield (Tian et al., 1994; Gehlet al., 2005, Anjorin 2013). The use of plant residues in combination with nitrogen was reported to have significantly increased dry matter yield and nutrient uptake in maize (Tian et al., 1994, Memon, et al, 2012) 
The objective of this study was to determine the comparative effects of weed-based organic materials on the growth and nutrient accumulation of maize.

\section{Materials and Methods}

The location of the field experiment was the Research Farm of the Agricultural Science Education Unit of the Delta State University, Abraka, Nigeria ((latitude $5^{0} 46^{\prime} \mathrm{N}$ and longitude $\left.6^{0} 5^{\prime} \mathrm{E}\right)$. The area has a bimodal rainfall with annual rainfall of $2323 \mathrm{~mm}$ and a mean temperature of $26.7^{\circ} \mathrm{C}$. The experiment was conducted during the 2011 and 2012 rainy seasons. Analysis of the surface soil (0$15 \mathrm{~cm}$ ) of the experimental site indicated the following properties: $47.3 \mathrm{~g} \mathrm{~kg}^{-1}$ organic matter, $0.72 \mathrm{~g}$ $\mathrm{kg}^{-1}$ total nitrogen, $\mathrm{pH}$ (in water) $5.7,778 \mathrm{~g} \mathrm{~kg}^{-1}$ sand, $98 \mathrm{gkg}^{-1}$ silt, $127 \mathrm{~g} \mathrm{~kg}^{-1}$ clay. The experiment consist of eight (8) treatments (i) control (ii) $40 \mathrm{kgNha}^{-1}$ (iii) $80 \mathrm{kgNha}^{-1}$ (iv) $120 \mathrm{kgNha}^{-1}$ (v) $4.5 \mathrm{t} \mathrm{ha}^{-}$ ${ }^{1}$ Panicum maximum $+40 \mathrm{kgNha}^{-1}$ (vi) $4.5 \mathrm{t} \mathrm{ha}^{-1}$ Pueraria phaseoloides $+40 \mathrm{kgNha}^{-1}$ (vii) $4.5 \mathrm{t} \mathrm{ha}^{-1}$ Eleusine indica $+40 \mathrm{kgNha}^{-1}$ (viii) $4.5 \mathrm{t} \mathrm{ha}^{-1}$ Stylosanthes gracilis $+40 \mathrm{kgNha}^{-1}$. The treatments were replicated thrice and arranged in a randomized complete block design on a plot size of $6 \mathrm{~m}$ by $4.5 \mathrm{~m}$, using a crop spacing of $90 \mathrm{~cm} \times 30 \mathrm{~cm}$.

Air dried weed materials were applied as mulch two days after maize was planted in 2011 and 2012. Nitrogen (urea) was applied in two equal splits, one and six weeks after planting (WAP). The maize variety was TZSR-Y. Plots were manually weeded at 2, 6 and 10 WAP. Growth parameters collected from the field were plant height, number of leaves, and leaf area. Leaf area was derived from the equation by Mokhtarpour et al. (2010) and stated as follows:

$\mathrm{Ln}(\mathrm{LA})=-0.990+1.231 \mathrm{Ln}(\mathrm{L})+0.854 \mathrm{Ln}(\mathrm{W})$, where $\mathrm{L}$ and $\mathrm{W}$ are the length and width of the maize leaf respectively.

Leaf area index (LAI) was determined using the formula by Palanisamy and Gomez (1974)

$\mathrm{LAI}=(\mathrm{L} \times \mathrm{W} \times 0.75 \times$ number of leaves/plant $) /($ Area occupied by plant $)$

In other to obtain crop growth rate data, three plants randomly harvested from each plot at 9 and 12 WAP, oven dried at $65^{\circ} \mathrm{C}$ to obtain the shoot dry matter. Derived growth parameters such as crop growth rate (CGR), relative growth rate (RGR) and net assimilatory rate (NAR) were estimated using the following equations.

$\mathrm{CGR}=\left(\mathrm{W}_{2}-\mathrm{W}_{1}\right) /\left(\mathrm{T}_{2}-\mathrm{T}_{1}\right)$ in $\mathrm{g} /$ day $($ Watson, 1948)

$\mathrm{RGR}=\left(\operatorname{loge}_{2}-\mathrm{loge}_{1}\right) /\left(\mathrm{T}_{2}-\mathrm{T}_{1}\right)$ in $\mathrm{g} /$ day $($ Williams, 1946)

$\mathrm{NAR}=\left[\left(\mathrm{W}_{2}-\mathrm{W}_{1}\right)\left(\operatorname{loge} \mathrm{L}_{2}-\operatorname{logeL}_{1}\right)\right] /\left[\left(\mathrm{T}_{2}-\mathrm{T}_{1}\right)\left(\mathrm{L}_{2}-\mathrm{L}_{1}\right)\right]$ in $\mathrm{g} \mathrm{dm}^{-3}$ day $^{-1}$ (Williams, 1946)

Where $\mathrm{L}, \mathrm{W}$ and $\mathrm{T}$ represents leaf area, shoot dry weights and time interval respectively.

Harvested plant samples of maize were ground to pass through a 20-mesh sieve for analysis using methods described by IITA (1979). The product of the mineral concentration of the plant shoot and its dry matter was used to obtain the nutrient uptake.

Results obtained were subjected to ANOVA and means separated using LSD at 5\% level of probability.

\section{Results and Discussion}

\subsection{Plant height and foliage characters}

There was an increase in maize plant height, leaf number, leaf area and leaf area index (LAI) in 2012 when compared to 2011 (Tables 1 and 2). Increased nitrogen application also resulted in higher plant height and foliage attributes up to $120 \mathrm{kgNha}^{-1}$. Significant $(P<0.05)$ increases in plant height, leaf number, leaf area and LAI were also observed with application of weed-based mulching materials in both years relative to the control. The $120 \mathrm{kgNha}^{-1}$ gave the highest plant height, leaf number, leaf area and LAI. The combination of Pueraria phaseoloides with $40 \mathrm{kgNha}^{-1}$ showed higher plant height and foliage development attributes compared to other combinations, while the combination of Panicum maximum and $40 \mathrm{kgNha}^{-1}$ showed the least vegetative growth characters.

The highest plant height of $181.6 \mathrm{~cm}(2011)$ and $187.0 \mathrm{~cm}$ (2012) was obtained in maize plants that received $120 \mathrm{kgNha}^{-1}$, while control treatment had the least value of $131.1 \mathrm{~cm} \mathrm{(2011)} \mathrm{and} 130.1$ (2012). Leaf number per plant ranged between 11.8 to 15.8 in 2011 and 10.2 to 15.5 in 2012. The 
LAI had values between 2.4 and 4.9 in 2011 and 2.0 and 5.0 in 2012. Generally plant height, leaf number, leaf area and LAI had were greater in 2012 compared to 2011 in nitrogen and nitrogen/mulch combinations, except in the control which had lower values in 2012 relative to 2011.

Table 1: Plant height, number of leaves and leaf area index of maize at 12WAP as influenced by nitrogen and mulching

\begin{tabular}{lllllll}
\hline & \multicolumn{2}{l}{ Plant height $(\mathrm{cm})$} & \multicolumn{2}{l}{ Leaf number } & \multicolumn{2}{l}{ LAI } \\
\hline Treatments & 2011 & 2012 & 2011 & 2012 & 2011 & 2012 \\
\hline Control & $131.1 \mathrm{e}$ & $130.1 \mathrm{e}$ & $11.8 \mathrm{c}$ & $10.2 \mathrm{c}$ & $2.4 \mathrm{~b}$ & $2.0 \mathrm{c}$ \\
$40 \mathrm{~N}$ & $150.3 \mathrm{~d}$ & $156.2 \mathrm{~d}$ & $13.7 \mathrm{~b}$ & $13.8 \mathrm{~b}$ & $3.6 \mathrm{a}$ & $3.6 \mathrm{ab}$ \\
$80 \mathrm{~N}$ & $165.2 \mathrm{~b}$ & $170.1 \mathrm{bc}$ & $13.2 \mathrm{~b}$ & $13.5 \mathrm{~b}$ & $4.0 \mathrm{a}$ & $4.0 \mathrm{ab}$ \\
$120 \mathrm{~N}$ & $181.6 \mathrm{a}$ & $187.0 \mathrm{a}$ & $15.3 \mathrm{a}$ & $15.5 \mathrm{a}$ & $4.9 \mathrm{a}$ & $5.0 \mathrm{a}$ \\
$4.5 \mathrm{t} /$ ha Panicum maximum $+40 \mathrm{~N}$ & $160.3 \mathrm{c}$ & $166.3 \mathrm{c}$ & $13.0 \mathrm{~b}$ & $13.3 \mathrm{~b}$ & $3.5 \mathrm{a}$ & $3.6 \mathrm{~b}$ \\
$4.5 \mathrm{t} /$ ha Pueraria phaseoloides $+40 \mathrm{~N}$ & $178.2 \mathrm{a}$ & $186.1 \mathrm{a}$ & $14.5 \mathrm{ab}$ & $14.8 \mathrm{ab}$ & $4.2 \mathrm{a}$ & $4.3 \mathrm{ab}$ \\
$4.5 \mathrm{t} /$ ha Eleusine indica $+40 \mathrm{~N}$ & $164.0 \mathrm{c}$ & $172.3 \mathrm{bc}$ & $14.1 \mathrm{ab}$ & $14.3 \mathrm{ab}$ & $3.9 \mathrm{a}$ & $4.0 \mathrm{ab}$ \\
$4.5 \mathrm{t} /$ ha Stylosanthes gracilis $+40 \mathrm{~N}$ & $175.3 \mathrm{ab}$ & $180.1 \mathrm{ab}$ & $14.0 \mathrm{ab}$ & $14.0 \mathrm{ab}$ & $4.0 \mathrm{a}$ & $4.1 \mathrm{ab}$ \\
LSD (5\%) & 10.2 & 11.7 & 1.8 & 1.7 & 1.4 & 1.3 \\
\hline
\end{tabular}

Table 2: Leaf area $\left(\mathrm{cm}^{2}\right)$ of maize at $9 \mathrm{WAP}$ and $12 \mathrm{WAP}$ as influenced by nitrogen and mulching

\begin{tabular}{lllll}
\hline & $9 \mathrm{WAP}$ & \multicolumn{3}{c}{$12 \mathrm{WAP}$} \\
\hline Treatments & 2011 & 2012 & 2011 & 2012 \\
\hline Control & $487.7 \mathrm{~d}$ & $460.3 \mathrm{~d}$ & $565.1 \mathrm{e}$ & $530.6 \mathrm{f}$ \\
$40 \mathrm{~N}$ & $672.5 \mathrm{c}$ & $682.5 \mathrm{c}$ & $703.8 \mathrm{~d}$ & $705.6 \mathrm{e}$ \\
$80 \mathrm{~N}$ & $760.3 \mathrm{~b}$ & $750.6 \mathrm{~b}$ & $801.3 \mathrm{~b}$ & $807.2 \mathrm{~b}$ \\
$120 \mathrm{~N}$ & $786.5 \mathrm{a}$ & $799.3 \mathrm{a}$ & $861.2 \mathrm{a}$ & $866.4 \mathrm{a}$ \\
$4.5 \mathrm{t} /$ ha Panicum maximum $+40 \mathrm{~N}$ & $681.8 \mathrm{c}$ & $670.3 \mathrm{c}$ & $730.6 \mathrm{~d}$ & $738.2 \mathrm{de}$ \\
$4.5 \mathrm{t} /$ ha Pueraria phaseoloides $+40 \mathrm{~N}$ & $746.5 \mathrm{~b}$ & $738.6 \mathrm{~b}$ & $783.1 \mathrm{c}$ & $790.0 \mathrm{c}$ \\
$4.5 \mathrm{t} /$ ha Eleusine indica $+40 \mathrm{~N}$ & $688.5 \mathrm{c}$ & $681.7 \mathrm{c}$ & $743.8 \mathrm{~d}$ & $751.2 \mathrm{~cd}$ \\
$4.5 \mathrm{t} /$ ha Stylosanthes gracilis $+40 \mathrm{~N}$ & $669.3 \mathrm{c}$ & $691.2 \mathrm{c}$ & $750.6 \mathrm{~cd}$ & $761.3 \mathrm{~cd}$ \\
LSD (5\%) & 39.8 & 40.3 & 40.7 & 37.5 \\
\hline
\end{tabular}

\subsection{Shoot dry weight}

From the data obtained at 9WAP and 12WAP, shoot dry weight of the maize plants was significantly $(P<0.05)$ increased by sole nitrogen application and combination of nitrogen and mulching materials (Table 3). Shoot dry weight was lower in 2012 than 2011 in the control treatment, while increase in dry weight was observed in $\mathrm{N}$ applications and $\mathrm{N}$ in combination with organic mulch. Shoot dry weight was highest in $120 \mathrm{kgNha}^{-1}$ and least in the control with values between 144.3 to $206.5 \mathrm{~g}$ in 2011 and 136.5 to $207.3 \mathrm{~g}$ in 2012 .

Nitrogen application treatments were higher than the control by $10.4 \% .13 .2 \%$ and $43.1 \%$ at 40,80 and $120 \mathrm{kgNha}^{-1}$ respectively in 2011 , while an increase of $17.4 \%, 25 \%$ and $51.9 \%$ was observed in 2012 for the respective nitrogen applications. Combination of nitrogen and mulch resulted in an increase of $14.4 \%, 31.8 \%, 20.1 \%$ and $36 \%$ using Panicum maximum, Pueraria phaseoloides, Eleusine indica and Stylosanthes gracilis respectively in 2011. During the 2012 cropping, an increase of $17.4 \%, 43.9 \%, 31.7 \%$ and $46.6 \%$ was observed for the same respective combinations. 
Table 3: Shoot dry weight of maize at 9 WAP and 12WAP as influenced by nitrogen and mulching

\begin{tabular}{lllll}
\hline & 9WAP & \multicolumn{3}{c}{$12 \mathrm{WAP}$} \\
\hline Treatments & 2011 & 2012 & 2011 & 2012 \\
\hline Control & $139.6 \mathrm{c}$ & $131.7 \mathrm{e}$ & $144.3 \mathrm{~d}$ & $136.5 \mathrm{~d}$ \\
$40 \mathrm{~N}$ & $153.7 \mathrm{~b}$ & $156.2 \mathrm{~d}$ & $159.8 \mathrm{c}$ & $160.2 \mathrm{c}$ \\
$80 \mathrm{~N}$ & $160.2 \mathrm{~b}$ & $163.8 \mathrm{bc}$ & $166.3 \mathrm{c}$ & $170.6 \mathrm{bc}$ \\
$120 \mathrm{~N}$ & $194.3 \mathrm{a}$ & $198.3 \mathrm{a}$ & $206.5 \mathrm{a}$ & $207.3 \mathrm{a}$ \\
$4.5 \mathrm{t} / \mathrm{ha}$ Panicum maximum $+40 \mathrm{~N}$ & $157.3 \mathrm{~b}$ & $160.2 \mathrm{~cd}$ & $165.1 \mathrm{c}$ & $168.2 \mathrm{c}$ \\
$4.5 \mathrm{t} /$ ha Pueraria phaseoloides $+40 \mathrm{~N}$ & $183.5 \mathrm{a}$ & $169.5 \mathrm{bc}$ & $190.2 \mathrm{ab}$ & $196.4 \mathrm{a}$ \\
$4.5 \mathrm{t} /$ ha Eleusine indica $+40 \mathrm{~N}$ & $169.2 \mathrm{~b}$ & $173.6 \mathrm{~b}$ & $173.3 \mathrm{bc}$ & $179.8 \mathrm{~b}$ \\
$4.5 \mathrm{t} /$ ha Stylosanthes gracilis $+40 \mathrm{~N}$ & $187.7 \mathrm{a}$ & $190.6 \mathrm{a}$ & $196.2 \mathrm{a}$ & $200.1 \mathrm{a}$ \\
LSD $(5 \%)$ & 12.6 & 13.1 & 20.8 & 14.5 \\
\hline
\end{tabular}

\subsection{Crop growth}

The influence of nitrogen levels and nitrogen + mulching materials on CGR, RGR and NAR is presented in Table 4. Under nitrogen application, significant response of CGR was observed only with $120 \mathrm{kgNha}^{-1}$ in 2011 , but nitrogen combined with Panicum maximum, Pueraria phaseoloides, and Stylosanthes gracilis indicated significant CGR over the control. CGR values were within the range of 0.20 and 0.58 in 2011 and 0.19 and $0.45 \mathrm{~g} /$ day in 2012. Lowest CGR was observed in $\mathrm{N}+$ Eleusine indica in 2011, while $40 \mathrm{~N}$ showed the least in 2012 . The $120 \mathrm{kgNha}^{-1}$ recorded the highest CGR in 2011, while the N + Stylosanthes gracilis recorded the highest value of $0.45 \mathrm{~g} /$ day in 2012. The RGR was more pronounced with the control. The values ranged between 0.0498 to 0.0549 g/day. No significant response of RGR to nitrogen and mulch application was observed in this study within the two cropping years.

NAR did not show any consistent trend increase with nitrogen application. NAR values ranged between 0.000156 to 0.000462 and 0.000172 to $0.000405 \mathrm{gdm}^{-3} \mathrm{day}^{-1}$ in 2011 and 2012 respectively. Pueraria phaseoloides combined with nitrogen and $40 \mathrm{kgNha}^{-1}$ had the highest NAR in both cropping years.

Table 4: Crop growth rate (CGR), relative growth rate (RGR) and net assimilatory rate (NAR) as influenced by nitrogen and mulching

\begin{tabular}{lllllll}
\hline & $\begin{array}{l}\text { CGR } \\
\text { (g/day) }\end{array}$ & & \multicolumn{2}{l}{$\begin{array}{l}\text { RGR } \\
\text { (g/day) }\end{array}$} & \multicolumn{2}{l}{$\begin{array}{l}\text { NAR } \\
\left(\mathrm{g} \mathrm{dm}^{-3} \text { day }^{-1}\right)\end{array}$} \\
\hline Treatments & 2011 & 2012 & 2011 & 2012 & 2011 & 2012 \\
\hline Control & & & $10^{-2}$ & $10^{-2}$ & $10^{-4}$ & $10^{-4}$ \\
$40 \mathrm{~N}$ & $0.22 \mathrm{c}$ & $0.22 \mathrm{~b}$ & 5.52 & 5.49 & $1.56 \mathrm{c}$ & $1.72 \mathrm{c}$ \\
$80 \mathrm{~N}$ & $0.29 \mathrm{bc}$ & $0.19 \mathrm{~b}$ & 4.98 & 4.92 & $4.62 \mathrm{a}$ & $4.05 \mathrm{a}$ \\
$120 \mathrm{~N}$ & $0.29 \mathrm{bc}$ & $0.32 \mathrm{ab}$ & 5.02 & 5.12 & $3.55 \mathrm{a}$ & $2.90 \mathrm{a}$ \\
$4.5 \mathrm{t} /$ ha Panicum maximum $+40 \mathrm{~N}$ & $0.58 \mathrm{a}$ & $0.43 \mathrm{a}$ & 5.21 & 5.16 & $3.76 \mathrm{a}$ & $3.31 \mathrm{a}$ \\
$4.5 \mathrm{t} /$ ha Pueraria phaseoloides $+40 \mathrm{~N}$ & $0.37 \mathrm{ab}$ & $0.38 \mathrm{ab}$ & 5.10 & 5.24 & $3.86 \mathrm{a}$ & $2.94 \mathrm{ab}$ \\
$4.5 \mathrm{t} /$ ha Eleusine indica $+40 \mathrm{~N}$ & $0.33 \mathrm{ab}$ & 5.00 & 5.09 & $4.37 \mathrm{a}$ & $3.27 \mathrm{a}$ \\
$4.5 \mathrm{t} /$ ha Stylosanthes gracilis $+40 \mathrm{~N}$ & $0.20 \mathrm{c}$ & $0.30 \mathrm{ab}$ & 5.14 & 5.25 & $1.86 \mathrm{c}$ & $2.27 \mathrm{bc}$ \\
LSD (5\%) & $0.40 \mathrm{ab}$ & $0.45 \mathrm{a}$ & 5.34 & 5.24 & $2.63 \mathrm{~b}$ & $3.37 \mathrm{a}$ \\
\hline
\end{tabular}

\subsection{Nutrient concentration and uptake}

The effect of nitrogen and mulching effects on nitrogen, phosphorus and potassium concentration and uptake in the maize shoots is presented in Tables 5 and $6 . \mathrm{N}$ concentration in maize shoot increased with application of nitrogen and $\mathrm{N}+$ mulch. Plants which received $120 \mathrm{~N}$, combination with $P$. phaseoloides and $S$. gracilis showed more N content with values of $18.30,15.21$ and 14.72 $\mathrm{g} \mathrm{kg}^{-1}$ respectively in 2011, and $19.62,16.11$ and $15.61 \mathrm{~g} \mathrm{~kg}^{-1}$ respectively in 2012. Except in control, N content increased in 2012 compared to 2011. 
$\mathrm{P}$ showed significant increase in response to $\mathrm{N}$ application and $\mathrm{N}+$ mulch. $\mathrm{P}$ increase in maize shoot was more pronounced with $\mathrm{N}$ in combination with organic mulch when compared with chemical nitrogen application alone. The range of $P$ was 0.90 to $2.21 \mathrm{~g} \mathrm{~kg}^{-1}$ in 2011 and 0.81 to 2.50 $\mathrm{g} \mathrm{kg}^{-1}$ in 2012. Application of $\mathrm{N}+$ legumes such as $P$. phaseoloides and $S$. gracilis showed higher $\mathrm{P}$ content with values of 2.50 and $2.32 \mathrm{~g} \mathrm{~kg}^{-1}$ respectively in 2011 and 2.50 and $2.32 \mathrm{~g} \mathrm{~kg}^{-1}$ in 2012 respectively.

Application of $\mathrm{N}$ in combination with weed-based mulch significantly increased $\mathrm{K}$ content of maize shoot. In 2011 and 2012, $\mathrm{K}$ values in plant shoots ranged from 4.61 to $19.71 \mathrm{~g} \mathrm{~kg}^{-1}$ and 4.31 to $21.33 \mathrm{~g} \mathrm{~kg}^{-1}$. The combination of mulch with chemical nitrogen showed a more pronounced increase in $\mathrm{K}$ compared to the various levels of only applied $\mathrm{N}$.

Application of $\mathrm{N}$ combined with mulch significantly increased nitrogen uptake in the maize shoot. Uptake of nitrogen was at its maximum at $120 \mathrm{kgNha}^{-1}$ rate with values of 139.06 and $150.59 \mathrm{kgha}^{-1}$ in 2011 and 2012 respectively. Maize plants mulched with $P$. phaseoloides and supplemented with $40 \mathrm{kgNha}^{-1}$ showed highest $\mathrm{N}$ uptake and was higher than the control by $189 \%$ and $400 \%$ in 2011 and 2012 respectively. The legume mulches showed higher nitrogen uptake than the grass mulches.

Table 5: Nitrogen, phosphorus and potassium concentration in maize shoot as influenced by nitrogen and mulching

\begin{tabular}{lllllll}
\hline & $\begin{array}{l}\mathrm{N} \\
\left(\mathrm{g} \mathrm{kg}^{-1}\right)\end{array}$ & & $\begin{array}{l}\mathrm{P} \\
\left(\mathrm{g} \mathrm{kg}^{-1}\right)\end{array}$ & \multicolumn{3}{c}{$\begin{array}{l}\mathrm{K} \\
\left(\mathrm{g} \mathrm{kg}^{-1}\right)\end{array}$} \\
\hline Treatments & 2011 & 2012 & 2011 & 2012 & 2011 & 2012 \\
\hline Control & $6.91 \mathrm{c}$ & $6.01 \mathrm{~d}$ & $0.90 \mathrm{c}$ & $0.81 \mathrm{~d}$ & $4.61 \mathrm{f}$ & $4.31 \mathrm{~d}$ \\
$40 \mathrm{~N}$ & $12.60 \mathrm{~b}$ & $12.83 \mathrm{c}$ & $1.22 \mathrm{~b}$ & $1.32 \mathrm{~cd}$ & $9.32 \mathrm{e}$ & $9.72 \mathrm{c}$ \\
$80 \mathrm{~N}$ & $14.82 \mathrm{~b}$ & $15.11 \mathrm{~b}$ & $1.45 \mathrm{ab}$ & $1.41 \mathrm{bcd}$ & $10.71 \mathrm{de}$ & $11.83 \mathrm{bc}$ \\
$120 \mathrm{~N}$ & $18.30 \mathrm{a}$ & $19.62 \mathrm{a}$ & $1.44 \mathrm{ab}$ & $1.53 \mathrm{bcd}$ & $12.91 \mathrm{ce}$ & $13.32 \mathrm{bc}$ \\
$4.5 \mathrm{t} /$ ha Panicum maximum $+40 \mathrm{~N}$ & $12.83 \mathrm{~b}$ & $13.20 \mathrm{c}$ & $1.62 \mathrm{ab}$ & $1.82 \mathrm{abc}$ & $14.82 \mathrm{bc}$ & $15.61 \mathrm{ab}$ \\
$4.5 \mathrm{t} /$ ha Pueraria phaseoloides $+40 \mathrm{~N}$ & $15.21 \mathrm{ab}$ & $16.11 \mathrm{~b}$ & $2.21 \mathrm{a}$ & $2.50 \mathrm{a}$ & $19.71 \mathrm{a}$ & $21.33 \mathrm{a}$ \\
$4.5 \mathrm{t} /$ ha Eleusine indica $+40 \mathrm{~N}$ & $13.11 \mathrm{~b}$ & $13.82 \mathrm{bc}$ & $1.72 \mathrm{ab}$ & $1.91 \mathrm{abc}$ & $16.21 \mathrm{ab}$ & $18.73 \mathrm{a}$ \\
$4.5 \mathrm{t} /$ ha Stylosanthes gracilis $+40 \mathrm{~N}$ & $14.72 \mathrm{a}$ & $15.61 \mathrm{~b}$ & $2.01 \mathrm{a}$ & $2.32 \mathrm{ab}$ & $18.30 \mathrm{a}$ & $20.01 \mathrm{a}$ \\
LSD $(5 \%)$ & 3.38 & 2.87 & 0.78 & 0.89 & 4.33 & 5.01 \\
\hline
\end{tabular}

Table 6: Nitrogen, phosphorus and potassium uptake in maize shoot as influenced by nitrogen and mulching

\begin{tabular}{lllllll}
\hline & $\begin{array}{l}\mathrm{N} \\
\left(\mathrm{kg} \mathrm{ha}^{-1}\right)\end{array}$ & & $\begin{array}{l}\mathrm{P} \\
\left(\mathrm{kg} \mathrm{ha}^{-1}\right)\end{array}$ & $\begin{array}{l}\mathrm{K} \\
\left(\mathrm{kg} \mathrm{ha}^{-1}\right)\end{array}$ \\
\hline Treatments & 2011 & 2012 & 2011 & 2012 & 2011 & 2012 \\
\hline Control & $37.00 \mathrm{e}$ & $30.34 \mathrm{e}$ & $4.81 \mathrm{~d}$ & $4.07 \mathrm{c}$ & $24.79 \mathrm{~d}$ & $21.83 \mathrm{~d}$ \\
$40 \mathrm{~N}$ & $74.37 \mathrm{~d}$ & $76.22 \mathrm{~d}$ & $7.03 \mathrm{~cd}$ & $7.77 \mathrm{~b}$ & $55.13 \mathrm{~cd}$ & $58.46 \mathrm{c}$ \\
$80 \mathrm{~N}$ & $91.02 \mathrm{bc}$ & $92.87 \mathrm{c}$ & $8.88 \mathrm{bc}$ & $8.88 \mathrm{~b}$ & $65.86 \mathrm{c}$ & $74.74 \mathrm{c}$ \\
$120 \mathrm{~N}$ & $139.06 \mathrm{a}$ & $150.59 \mathrm{a}$ & $11.10 \mathrm{~b}$ & $11.84 \mathrm{~b}$ & $98.79 \mathrm{~b}$ & $102.12 \mathrm{~b}$ \\
$4.5 \mathrm{t} /$ ha Panicum maximum $+40 \mathrm{~N}$ & $78.44 \mathrm{c}$ & 82.14 & $9.99 \mathrm{bc}$ & $11.47 \mathrm{~b}$ & $90.65 \mathrm{~b}$ & $119.86 \mathrm{~b}$ \\
$4.5 \mathrm{t} /$ ha Pueraria phaseoloides $+40 \mathrm{~N}$ & $106.93 \mathrm{~b}$ & $116.92 \mathrm{~b}$ & $15.59 \mathrm{a}$ & $18.13 \mathrm{a}$ & $138.75 \mathrm{a}$ & $154.66 \mathrm{a}$ \\
$4.5 \mathrm{t} /$ ha Eleusine indica $+40 \mathrm{~N}$ & $83.99 \mathrm{~cd}$ & $91.76 \mathrm{c}$ & $11.10 \mathrm{~b}$ & $12.58 \mathrm{~b}$ & $103.97 \mathrm{~b}$ & $124.69 \mathrm{~b}$ \\
$4.5 \mathrm{t} /$ ha Stylosanthes gracilis $+40 \mathrm{~N}$ & $101.92 \mathrm{~b}$ & $115.44 \mathrm{~b}$ & $16.65 \mathrm{a}$ & $17.02 \mathrm{a}$ & $132.83 \mathrm{a}$ & $148.00 \mathrm{a}$ \\
LSD (5\%) & 15.3 & 17.2 & 3.56 & 4.97 & 28.31 & 23.17 \\
\hline
\end{tabular}

Phosphorus uptake in response to $\mathrm{N}$ and mulch was observed to be higher with combination of mulch and nitrogen compared to only applied mineral nitrogen. $\mathrm{P}$ uptake was higher in $\mathrm{N}$ combined S. gracilis. P uptake values ranged from 4.81 to 16.65 in 2011 and 4.07 to 18.13 in 2012.

Application of organic mulches supplemented with chemical N significantly increased $\mathrm{K}$ uptake in maize plants, compared to applying nitrogen alone. Relative to the control, mulching increased the K uptake of the maize shoots by above 200\% in all mulch treatments in both 2011 and 2012, while nitrogen treatment increased $\mathrm{K}$ uptake above $100 \%$. 


\section{Discussion}

Nitrogen has a significant role it plays in plant biochemical constituents, especially for nitrogen demanding crops such as cereals. Nitrogen promoted vegetative growth of maize as observed in this study, hence the positive response noted with application of urea. The increase in plant height in response to $\mathrm{N}$ application could be attributed to increase in foliage characters such as number of leaves, leaf area and leaf area index (LAI) associated with higher light interception. Greater plant height and foliage development also influenced photosynthetic activities production which were translocated to various sinks resulting in positive dry matter production of the maize plants.

Increases in maize plant height, leaf development attributes, dry matter production and nutrient uptake when weed based organic mulch with varied chemical composition were applied, showed the significant role that weed mulch can play in sustaining crop productivity. Dry leguminous organic materials such as $P$. phaseoloides and $S$. gracilis contributed significantly to the growth biomass production of the crop through their high nutrient release, since they are easily decomposable. These legumes are known to have low lignin and $\mathrm{C} / \mathrm{N}$ ratio and low polyphenol contents and as such classified as high quality mulch materials (Tian et al., 1994). The high nutrient concentration and uptake when $\mathrm{N}$ was added to the soil partially in the form of weed based organic mulch, indicates the significant role of combining plant materials with mineral nitrogen fertilizer to increase crop performance. These observations were confirmed by earlier studies (Tian et al., 1994). It also confirms the reports of Memnon et al. (2012) which showed higher macronutrient (N,P and $\mathrm{K})$ translocation efficiency with organic amendments. The reduced soil acidification with reduction in mineral fertilizer nitrogen may also have indirectly promoted the bioavailability of nutrients for uptake by the maize plants as earlier observed by other researchers (Fageria, 2004; Skowrońska and Filipek, 2010)

Generally the control treatment with no applied nitrogen or organic mulch showed significant lower plant height, leaf production attributes, dry matter production, growth rates and nutrient uptake. This indicates the effect of nitrogen limitation on foliage production indices and photosynthetic and assimilatory capacity in a $\mathrm{C}_{4}$ cereal crop, such as maize. This result is in agreement with other studies (Bange, 1995; Vox et al., 2005). Other related studies (Andrade and Uhart, 1995; Abayomi et al., 2006) also showed reduced maize leaf growth indices with nitrogen shortage, which further reduced dry matter production as a result of lower radiation interception and poor partitioning of dry matter to reproductive sinks.

\section{Conclusion}

This study has shown that mulching with weed based residues, especially leguminous weeds such as Pueraria phaseoloides, and Stylosanthes gracilis has much effect on the performance of maize. Since these residues have high $\mathrm{C} / \mathrm{N}$ ration with low lignin, they are potential quality organic materials that could contribute to reducing quantity of chemical nitrogen fertilizer. This will contribute to enhance the soil productivity and reduce cost of maize production.

\section{References}

[1] Abayomi, Y.A., Airejenja-George, A. and Kolawole, I.A (2006) Comparative leaf growth and grain yield responses of hybrid and open pollinated maize genotypes to nitrogen fertilizer application Agrosearch 8(1):13-35

[2] Ademiluyi, I.O. (2014) Adoption of improved maize varieties among farmers in Bassa Local Government Area of Plateau state, Nigeria International Journal of Innovative Agriculture \& Biology Research 2 (4):26-33

[3] Akobundu, I.O. (1993) Integrated weed management techniques to reduce soil degradation IITA IITA Research 6:11-16 
[4] Andrade, F.H. and Uhart, S.A. (1995) Nitrogen deficiency in maize (1): Effect of crop growth, development and dry matter partitioning and kernel set Crop Science 35:1376-1383

[5] Anjorin, F.B. (2014) Comparative Growth and Grain Yield Response of Five Maize Varieties to Nitrogen Fertilizer Application Greener Journal of Agricultural Sciences 3(12):801-808

[6] Bange M.P. (1995) Environmental control of potential yield of sunflower in a sub-tropical environment. PhD Thesis, The University of Queensland, Brisbane, Australia.

[7] Ehui, S.K., Spencer, D.S.C. (1994) Measuring the sustainability and economic viability of tropical farming systmes: A model from Sub-Saharan Africa IITA Research 9:1-6

[8] Fageria N.K. (2004) Dry matter yield and shoot nutrient concentrations of upland rice, common bean, corn, and soybean grown in rotation on an Oxisol. Comm. Soil Sci. Plant Anal.35:961-974

[9] Gehl R.J., Schimdt J.P., Maddux L.D, Gordon W.B. (2005). Corn yield response to nitrogen rate and timing in sandy irrigated soils. Agron.J., 97:1230-1238.

[10] Kehinde, J.K. (1999) Maize development at the National Cereals Research Institute In: Valencia, J.A.M., S. Miko and S.G. Ado Proceedings of the National Maize Workshop, pp.62

[11] Memon, M., K. S. Memon, S. Mirani, and G. M. Jamro (2012) Comparative evaluation of organic wastes for improving maize growth and NPK content African Journal of Biotechnology Vol. 11(39):9343-9349

[12] Mokhtarpour, Hassan; Christopher B.S. ;Teh, Ghizan Saleh; Ahmad B. Selamat; Mohammad E. Asadi; Behnam Kamkar (2010) Non-destructive estimation of maize leaf area, fresh weight, and dry weight using leaf length and leaf width Communications in Biometry and Crop Science 5(1):19-26

[13] Palanisamy, K.M. and Gomez, K.A. (1974) Length width method for estimating leaf area of rice Agronomy Journal 66: 430-433

[14] Skowrońska, M. and T. Filipek (2010) Accumulation Of Nitrogen And Phosphorus By Maize As The Result Of A Reduction In The Potassium Fertilization Rate Ecological Chenistry and Engineering 17(1):83-88

[15] Tian, G.; Kang, B.T., Brussaard, L. (1994) Mulching effect of plant residues with chemically contrasting compositions on maize growth and nutrients accumulation IITA Research 9:7-10

[16] Vos,J.,, P.E.L. van der Putten; C.J. Birch (2005)Effect of nitrogen supply on leaf appearance, leaf growth, leaf nitrogen economy and photosynthetic capacity in maize (Zea mays L.) Field Crops Research 93: 64-73

[17] Watson, D.J. (1948) The dependence of net assimilatory rate on leaf index Annals of Botany $22: 37-54$

[18] Williams, R.F. (1946) Physiology of plant growth with reference to the concept of net assimilatory rate Annals of Botany 10:41-72 